Per-Olof Joachimsson MD, Sven-Olof Nyström MD PHD, Hans Tydén MD PH D

\title{
Postoperative ventila- tory and circulatory effects of extended rewarming during cardiopulmonary bypass
}

Postoperative effects of extended rewarming (ECR) after hypothermic cardiopulmonary bypass $(C P B)$ were studied. All $(n=$ 28) patients were rewarmed to a nasopharyngeal remperature exceeding $38^{\circ} \mathrm{C}$ before terminating CPB. In 12 patients (control group) the rectal temperature $\left(T_{\text {re }}\right)$ was $33.8 \pm 1.7^{\circ} \mathrm{C}$ (mean \pm sd) at termination of $C P B$. In sixteen patients ( $E C R$ group) rewarming during $C P B$ was continued to a $T_{r e}$ of $36.8 \pm 0.5^{\circ} \mathrm{C}$. Postoperative body temperatures, heat content, shivering, oxygen uptake, $\mathrm{CO}_{2}$ production and haemodynamic variables were measured. ECR reduced the heat gain required to complete core rewarming to $665 \pm 260 \mathrm{~kJ}$, compared with $1037 \pm 374 \mathrm{~kJ}$ in the control group $(p<0.01)$. The incidence of shivering was reduced ( $p<0.05$ ) as well as shivering intensity and duration. In seven non-shivering ECR group patients this coincided with significantly reduced metabolic and ventilatory demands but these improvements were not valid for the group as a whole. The required ventilation temporarily during postoperative rewarming in both groups increased to 250 per cent of the basal need. Extending $C P B$ rewarming (to at least $36^{\circ} \mathrm{C} \quad T_{\text {re }}$ ) was inefficient when used as the sole measure to reduce the untoward effects of residual hypothermia during recovery after cardiac surgery with hypothermic $C P B$.

\section{Key words}

HYPOTHERMIA: shivering; OXYGEN: consumption, uptake; SURGERY: cardiovascular, cardiopulmonary bypass; TEMPERATURE: body, metabolism monitoring.

From the Departments of Anaesthesiology and Intensive Care, and Thoracic Surgery (S.-O. N.), Uppsala University. Akademiska sjukhuset, S-751 85 Uppsala, Sweden.

Address correspondence to: Dr. P.-O. Joachimsson.

The investigation was supported in part by grants from the Swedish National Association against Heart and Chest Diseases.
Temperature gradients exist between different parts of the body during rewarming after hypothermic cardiopulmonary bypass (CPB). ${ }^{1}$ The body core is rewarmed faster than the superficial shell, and the latter is comprised of musculature as well as subcutaneous tissues and skin. Redistribution from the warmer core to the cooler shell tissues occurs due to the heterogeneous distribution of heat. Combined with heat loss to the environment, this causes an after-drop of core temperature when rewarming is stopped at termination of CPB. ${ }^{2,3}$ Thus there is unintentional hypothermia present at the beginning of the postoperative period. The after-drop of temperature can be reduced if rewarming during $C P B$ is continued not only until normalization of core temperature but also until other tissues such as muscle and skin have reached at least $30.0^{\circ} \mathrm{C}{ }^{4}$ Recent results also indicate that rewarming to a urinary bladder or rectal temperature of at least $36^{\circ} \mathrm{C}$ minimized the after-drop of core temperature. ${ }^{5}$ Postoperative hypothermia is accompanied by an increased metabolic load during the ensuing postoperative rewarming after cardiac surgery as well as after general surgical procedures. ${ }^{6,7}$ We have found previously that it is possible to ameliorate the untoward effects of hypothermia after cardiac surgery by the use of postoperative radiant heat. ${ }^{8}$

The purpose of this study was to evaluate whether extending the rewarming during cardiopulmonary bypass in order to produce a rectal temperature of at least $36^{\circ} \mathrm{C}$ would improve the unfavourable effects caused by residual postoperative hypothermia, e.g., shivering, increased oxygen uptake and vasoconstriction.

\section{Methods}

Twenty-eight men with stable angina pectoris were studied prospectively in the early postoperative period after aortocoronary bypass surgery. Informed consent and approval by the Institutional Review Board of the Medical Faculty, Uppsala University, were obtained. Patients scheduled for elective surgery were considered for the study if they had good or only moderately impaired left 
TABLE I Anthropometric data and estimated basal ventilation (at $37^{\circ} \mathrm{C}$ body temperature)

\begin{tabular}{lcc}
\hline & Control group & ECR group \\
\hline No. of patients & 12 & 16 \\
Age (years) & $55 \pm 12$ & $56 \pm 6$ \\
Weight (kg) & $78 \pm 10$ & $80 \pm 8$ \\
Height (cm) & $172 \pm 6$ & $176 \pm 5$ \\
Body surface area $\left(\mathrm{m}^{2}\right)$ & $1.93 \pm 0.14$ & $1.97 \pm 0.11$ \\
$\begin{array}{l}\text { Estimated ventilation, } \\
\mathrm{f}=10\left(\mathrm{~L} \text { min }^{-1}\right)\end{array}$ & $6.7 \pm 0.5$ & $6.7 \pm 0.4$ \\
\hline
\end{tabular}

Mean \pm SD. No statistically significant differences between the group were seen.

ventricular function. This was judged from the preoperative left ventricular angiogram by estimation of ventricular wall motion and as an ejection fraction above 0.50 . All patients were receiving $\beta$-blocking agents, the last dose of which was given with premedication on the day of operation. Patients were excluded if they had manifest cardiac failure, uncontrolled hypertension or required medication for congestive failure. Previously known and well controlled hypertension was present in about 50 per cent of the patients equally distributed between the two study groups. First a control group of 12 patients was investigated in order to describe the early postoperative course following our routine intraoperative procedures. According to that protocol the end point for rewarming during CPB was oesophageal and nasopharyngeal temperatures reaching at least $38^{\circ} \mathrm{C}$. Then 16 consecutive patients were selected to form the extended $\mathrm{CPB}$-rewarming group (ECR group). For those patients the protocol was altered to provide extended rewarming during CPB which was continued after the oesophageal and nasopharyngeal temperatures had reached $38^{\circ} \mathrm{C}$ and not terminated until the rectal temperature had reached at least $36^{\circ} \mathrm{C}$. During anaesthesia and the postoperative investigation period all patients were attended by the same investigator (P.-O. J.) but several surgeons were engaged in both groups. Anthropometric data are given in Table I.

\section{Anaesthesia}

The control patients were given a sedative containing barbiturates and hydroxyzine (Vesparax ${ }^{\oplus}, \mathrm{UCB}$ ) and in the ECR group $2 \mathrm{mg}$ of flunitrazepam (Rohypnol ${ }^{\circledR}$, Roche) was used on the night before the operation. About $1.5 \mathrm{~h}$ before anaesthesia all patients were premedicated with $10 \mathrm{mg}$ of morphine chloride and $0.4 \mathrm{mg}$ of scopolamine bromide (Morfinskopolamin ${ }^{\star}, \mathrm{ACO}$ ) given intramuscularly. Anaesthesia was induced with phenoperidine (Lealgin ${ }^{\otimes}$, Leo) $0.1 \mathrm{mg} \cdot \mathrm{kg}^{-1}$ intravenously (IV) and 50-200 $\mathrm{mg}$ of thiopentone IV, and pancuronium bromide $0.1 \mathrm{mg} \cdot \mathrm{kg}^{-1}$ was used for muscular relaxation. The anaesthesia was maintained with nitrous oxide in
TABLE II Surgical procedures and intraoperative temperature balance

\begin{tabular}{lcr}
\hline & Control group & ECR group \\
\hline Number of grafts & $2.7(1-4)$ & $3.2(2-4)$ \\
Number of distal anastamoses & $3.2(1-5)^{*}$ & $4.3(2-6)$ \\
CPB-time (min) & $110 \pm 41$ & $133 \pm 33$ \\
Aortic crossclamping time (min) & $71 \pm 28$ & $85 \pm 27$ \\
Time between end of CPB & & \\
$\quad$ and Ist measurement (h) & $2.2 \pm 0.5$ & $1.9 \pm 0.2$ \\
$\mathrm{~T}_{\text {re, end of CPB }\left({ }^{\circ} \mathrm{C}\right)}$ & $33.8 \pm 1.7 \ddagger$ & $36.8 \pm 0.5$ \\
$\mathrm{~T}_{\text {oes }}$, end of CPB $\left({ }^{\circ} \mathrm{C}\right)$ & $38.2 \pm 0.7$ & $38.7 \pm 0.5$ \\
$\mathrm{~T}_{\text {re }}$, end of anaesthesia $\left({ }^{\circ} \mathrm{C}\right)$ & $35.0 \pm 0.9 \ddagger$ & $36.4 \pm 0.7$ \\
$\mathrm{~T}_{\text {oes, }}$, end of anaesthesia $\left({ }^{\circ} \mathrm{C}\right)$ & $34.7 \pm 0.9 \ddagger$ & $36.2 \pm 0.8$ \\
\hline
\end{tabular}

Mean and (range) or \pm SD are given. $*=p<0.05, t=p<0.01$, $\ddagger=p<0.001$.

oxygen and intermittent IV doses of phenoperidine and pancuronium. The total intraoperative dose of phenoperidine was $0.30 \pm 0.06 \mathrm{mg} \cdot \mathrm{kg}^{-1}$ (mean $\pm \mathrm{SD}$ ). During $\mathrm{CPB}$ an additional $50-200 \mathrm{mg}$ of thiopentone was given . Mechanical ventilation producing a $\mathrm{PCO}_{2}$ of $4.0-5.0 \mathrm{kPa}$ was used.

\section{Surgical procedures and cardiopulmonary bypass} Aortocoronary bypass vein grafting was performed in all patients. Data on the revascularisation procedures are given in Table II. Standard cardiopulmonary bypass with a bubble oxygenator and haemodilution (aiming at a haematocrit of 25 per cent) was used. The patients were cooled during bypass to a nasopharyngeal temperature of $25^{\circ} \mathrm{C}$. During rewarming the temperature of the water in the heating unit supplying the heat exchanger was gradually increased to $40^{\circ} \mathrm{C}$, but was never allowed to exceed the temperature of venous return perfusate by more than $10^{\circ} \mathrm{C}$. In both groups rewarming was continued until a nasopharyngeal temperature of at least $38^{\circ} \mathrm{C}$ was reached. In the controls CBP was then terminated as soon as surgery and spontaneous circulation permitted, whereas in the ECR group CPB and rewarming was continued until a rectal temperature of at least $36^{\circ} \mathrm{C}$ was reached.

\section{Postoperative care}

Postoperative mechanical ventilation was provided as synchronized intermittent mandatory ventilation (SIMV) by means of an ERICA ventilator (Engström Medical AB, Sweden). A fixed tidal volume was set according to the nomogram of Engström and Herzog, ${ }^{9}$ to provide an estimated basal ventilation (at $37^{\circ} \mathrm{C}$ body temperature) at a mandatory frequency of ten breaths per minute. The frequency of mandatory breaths was then altered as needed aiming at a $\mathrm{PCO}_{2}$ of $4.5-5.5 \mathrm{kPa}$. The adjustments were guided by end-tidal $\mathrm{CO}_{2}$ monitoring. As was the case during the operation, no heat or moisture conserving devices were used. Transfusions were passed 
through blood warmers at $37^{\circ} \mathrm{C}$. Analgesics (1-2 mg of ketobemidone) and sedatives (2.5-10 $\mathrm{mg}$ of diazepam) were given after first checking that ventilation was adequate, when patients were having pain, were obviously restless or indicated the need for additional medication. Packed red cells and plasma were given to achieve a haematocrit of 30-35 per cent and to maintain stable right and left atrial pressures. No patient needed inotropic support or vasodilating agents postoperatively.

\section{Investigation scheme}

The first set of measurements was made 30 min after admission to the $\mathrm{ICU}$. Muscular relaxation was reversed after this set of measurements was completed using 1.0 $\mathrm{mg}$ of atropine and $2.5 \mathrm{mg}$ of neostigmine. The measurements were repeated hourly. The control patients were studied during a period of 8-10 h, until they could be extubated. However, in this group, as well as in previous studies, ${ }^{8,10}$ both circulatory and ventilatory variables remained stable after cessation of shivering and core rewarming. Thus, in the ECR group the measurements were continued only beyond the time when rewarming had ceased (core temperature was unchanged or decreased during the hour interval since the preceding measurement occasion) and the condition was observed to remain stable. All patients in the ECR group were, thus, followed through the first four postoperative hours, and five patients were observed for $5 \mathrm{~h}$. All measurements in both groups were performed while the patients were ventilated mechanically.

\section{Laboratory methods and calculations}

\section{HAEMODYNAMIC MEASUREMENTS}

Pressures were monitored in the radial artery, pulmonary artery, left atrium and right atrium. The heart rate was derived from the electrocardiogram. Cardiac output was determined by the thermodilution technique using iced saline as indicator. The variation coefficient of the cardiac output determinations was $4.4 \pm 3.9$ per cent (SD).

\section{BLOOD GAS AND ACID-BASE ANALYSES}

Arterial and mixed venous blood samples were analysed in duplicate for $\mathrm{pH}, \mathrm{PO}_{2}, \mathrm{PCO}_{2}$ and base excess $(\mathrm{BE})$ in an ABL2 blood gas analyser (Radiometer, Denmark). Oxygen saturation and haemoglobin concentration (Hb) were measured in an OSM2 oximeter (Radiometer, Denmark). The samples were analysed at $37^{\circ} \mathrm{C}$ and the results are presented uncorrected for actual body temperature. ${ }^{11}$

\section{VENTILATORY GAS MEASUREMENTS}

Expired gas from the ventilator passed through a mixing chamber and the $\mathrm{CO}_{2}$ tension $\left(\mathrm{PeCO}_{2}\right)$ was measured by means of an infrared $\mathrm{CO}_{2}$ analyser (Capnometer 47210A, Hewlett \& Packard, Calif, USA). The expired gas volume was recorded by a spirometer (ventilation monitor LS.75, Bourns Medical Systems, Inc., Calif, USA) as the mean of two- or three-minute volumes. This ventilation volume was corrected to the actual core temperature, ambient pressure and saturated water vapour (BTPS).

\section{TEMPERATURES}

Temperatures were recorded on an electric 12-channel monitor (type d1 79, Ellab, Denmark) and oesophageal, rectal and skin thermistor probes were used. Skin temperatures were measured on the dorsal aspect of the middle phalanx of the third finger ( $T_{\tilde{f}}$ ), and on the four sites (the upper arm, the nipple, the mid-thigh and the mid-calf) required for calculation of mean skin temperature according to Ramanathan. ${ }^{12}$ The oesophageal temperature $\left(\mathrm{T}_{\text {oes }}\right)$ was recorded from the lower fourth of the oesophagus, the probe position being verified on the postoperative chest $x$-ray. In both groups the skin probes were insulated from the environment by covering them with pads of rubber foam. The measuring unit and all thermistor probes were calibrated against a precision mercury-in-glass thermometer in a thermostated water bath. They were accurate to $\pm 0.1^{\circ} \mathrm{C}$ over a range of $20-45^{\circ} \mathrm{C}$

\section{MUSCULAR HYPERACTIVITY}

Shivering and increases in muscular tone were estimated by inspection and palpation of mainly the jaw, pectoral and arm muscles and by testing the resistance to passive movements at the elbow joint. They were graded as: $0=$ none, $1=$ moderate and $2=$ pronounced. The scores of these two variables were added to form a "shivering score" with five levels $0-4$. Muscular activity was al ways estimated by the same investigator and assistant nurse independently, but always with agreeing result.

\section{CALCULATIONS OF DERIVED VARIABLES}

The mean skin temperature (MST) was calculated accord ing to the weighted formula of Ramanathan using four skin sites: ${ }^{12}$

MST $=0.3\left(\mathrm{~T}_{\text {nipple }}+\mathrm{T}_{\text {arm }}\right)+0.2\left(\mathrm{~T}_{\text {thigh }}+\mathrm{T}_{\text {calf }}\right),\left({ }^{\circ} \mathrm{C}\right)$.

The mean body temperature (MBT) and total body heat (TBH) were calculated from the standard formulae of Burton: ${ }^{13}$

$\mathrm{MBT}=0.66 \cdot \mathrm{T}_{\text {oes }}+0.34 \cdot \mathrm{MST},\left({ }^{\circ} \mathrm{C}\right)$, $\mathrm{TBH}=\mathrm{MBT} \cdot 3.47 \cdot$ body weight, $(\mathrm{kJ})$.

The change in total body heat during the time intervals between consecutive measurements was calculated and presented as $\triangle T B H$

Stroke volume index $(\mathrm{SI})=\mathrm{CI} \cdot 1000 / \mathrm{HR},\left(\mathrm{ml} \cdot \mathrm{m}^{-2}\right)$ 
Systemic vascular resistance $($ SVR $)=($ MAP - MRAP $)$. $60 / \mathrm{CO}\left(10^{6} \cdot \mathrm{N} \cdot \mathrm{s} \cdot \mathrm{m}^{-5}\right)$

The mean arterial (MAP) and mean right atrial (MRAP) pressures are given in $\mathrm{kPa}$, cardiac output $(\mathrm{CO})$ in $\mathrm{L} \cdot \mathrm{min}^{-1}$, cardiac index $(\mathrm{CI})$ in $\mathrm{L} \cdot \mathrm{min}^{-1} \cdot \mathrm{m}^{-2}$ and heart rate (HR) in beats $\cdot \mathrm{min}^{-1}$.

The oxygen contents of arterial and mixed venous blood were calculated from the following formula:

$\mathrm{Hb} \cdot 0.00062 \cdot \mathrm{SO}_{2}+\mathrm{PO}_{2} \cdot 0.01\left(\mathrm{mmol} \cdot \mathrm{L}^{-1}\right)$, where $\mathrm{Hb}$ is given in $\mathrm{g} \cdot \mathrm{L}^{-1}, \mathrm{SO}_{2}$ in per cent and $\mathrm{PO}_{2}$ in $\mathrm{kPa}$.

$\mathrm{O}_{2}$-delivery $=$ arterial oxygen content $\cdot$ cardiac index $/ 60$ $\left(\mathrm{mmol} \cdot \mathrm{s}^{-1} \cdot \mathrm{m}^{-2}\right)$. Oxygen utilization coefficient $\left(\mathrm{O}_{2} \mathrm{u} \mathrm{c}\right)$ was calculated by subtracting the mixed venous from the arterial oxygen content and dividing the result by the arterial oxygen content.

Oxygen uptake index $\left(\dot{\mathrm{V}}_{2} \mathrm{I}\right)=$ arteriovenous oxygen content difference $\mathrm{Cl} / 60\left(\mathrm{mmol} \cdot \mathrm{s}^{-1} \cdot \mathrm{m}^{-2}\right)$.

The measured $\mathrm{PECO}_{2}$ was converted to gas volume fraction $\left(\mathrm{FECO}_{2}\right)$. Carbon dioxide production index $\left(\mathrm{VCO}_{2} \mathrm{I}\right)$ $=\mathrm{FECO}_{2} \cdot \dot{\mathrm{V}}_{\mathrm{EBTPS}} /$ body surface area $\cdot \mathrm{C}_{\mathrm{f}}\left(\mathrm{mmol} \cdot \mathrm{s}^{-1} \mathrm{~m}^{-2}\right)$, where $\mathrm{C}_{\mathrm{f}}$ is the correction factor for transforming the gas volume to STPD-conditions and to the appropriate measuring unit.

\section{Statistics}

Statistical analyses were done with a statistical program package adapted for use in a personal computer. Descriptive statistics were calculated according to standard formulae. Each presented variable was evaluated during the first four postoperative hours in both groups. A two-factor analysis of variance model for repeated measures on one factor was used. ${ }^{8.14}$

The computational procedure was that of the least squares procedure, allowing for unequal group sizes. The results of this analysis are presented as $\mathrm{p}$ values for the main effects of the two factors "group," $p\left(F_{g}\right)$, and "measurement" or "phase," $p\left(F_{m}\right)$, and for their interaction effect, $p\left(F_{g \cdot m}\right)$. If $p\left(F_{g}\right)$ were low, then there would be a statistically significant difference between groups over the study period. If $\mathrm{p}\left(\mathrm{F}_{\mathrm{m}}\right)$ were low, then the measured variable would alter significantly with respect to measurements. A significant group/measurement interaction, $\mathrm{p}\left(\mathrm{F}_{\mathrm{g} \cdot \mathrm{m}}\right)$, would suggest that between two or more measurements the data of the two groups would evolve significantly differently. When the overall analysis indicated differences between groups, the two groups were compared at each measurement with the use of Student's $t$ test for unpaired data and using Bonferroni's adjustment to compensate for the multiple use of the $t$ test analysis. Ordinal data were analysed by the Mann-Whitney U-test.
Differences in proportions were analysed by Fisher's exact test. A p value less than 0.05 was considered significant.

\section{Results}

Data on surgical procedures and rewarming are summarized in Table II. More distal anastomoses were needed for revascularization in the ECR group. However, aortic crossclamping time, as well as CPB-time in spite of extended rewarming, did not differ between the groups. Patients in the control group were rewarmed during CPB to a mean rectal temperature $\left(\mathrm{T}_{\mathrm{re}}\right)$ of $33.8^{\circ} \mathrm{C}$ (range 30.8-35.9). Rewarming in the ECR group resulted in a mean $\mathbf{T}_{\mathrm{re}}$ of $36.8^{\circ} \mathrm{C}$ (range $36.0-37.7$ ). At the end of the operation and anaesthesia both $T_{\text {oes }}$ and $T_{\text {re }}$ were close to $35^{\circ} \mathrm{C}$ in the control group, while these temperatures in the ECR group were $36.2 \pm 0.8$ and $36.4 \pm 0.7^{\circ} \mathrm{C}$, respectively. The times from termination of rewarming and CPB to the end of the operation as well as to the first postoperative measurement were similar in the two groups. In both groups there was a fall in $T_{\text {oes }}$ from the end of CPB to the end of anaesthesia. The mean and range of this after-drop were $2.8^{\circ} \mathrm{C}(1.5-5.8)$ in the control group and $2.5^{\circ} \mathrm{C}(1.4-4.8)$ in the ECR group.

\section{Clinical course}

The postoperative course was characterized by four distinct phases. Phase I was the baseline measurement before muscular relaxation was reversed. Phase II was characterized by a maximal increase in $\mathrm{T}_{\text {oes }}$. Shivering, when present, always was associated with the increase in $T_{\text {ves. Moreover, the peak intensity of shivering always }}$ coincided with the most rapid rise in $\mathbf{T}_{\text {oes }}$. In phase IIl the $T_{\text {oes }}$ rise levelled off on a supranormal plateau. During phase IV there was a steep rise in peripheral cutaneous temperature, $\mathbf{T}_{\mathrm{f}}$.

The patients in the ECR group required less analgesics and less additional sedation than the controls $(p<0.01)$. Ventilation support was required during similar lengths of time in both groups, $9.1 \pm 2.0 \mathrm{~h}$ in the controls and 10.4 $\pm 3.6 \mathrm{~h}$ in the ECR group. The amount of intraoperative bleeding, urinary output, transfusions and crystalloid infusions were similar in both groups. Postoperative blood loss and fluid balance did not differ between the two groups. There were no differences with respect to postoperative serum levels of creatine kinase-MB (CKMB) or aspartate amino-transferase (ASAT).

No complications which could be attributed to the investigation procedures were noted.

\section{Heat balance (Figure 1)}

$T_{\text {oes }}$ was higher in the ECR group than in the control group until it levelled off on a warm plateau in both groups. The 
TABLE III Relative change (\%), from baseline measurement (phase I) to subsequent phases II-IV, of oxygen uplake index $\left(\Delta \mathrm{VO}_{2} \mathrm{I}\right)$ and carbon dioxide production index $\left(\Delta \mathrm{VCO}_{2} \mathrm{I}\right)$ and relative deviation $(\%)$ of actual ventilation volume ( $\left.\Delta \dot{V}_{\mathrm{E}} \mathrm{BTPS}\right)$ from basal estimated ventilation

\begin{tabular}{|c|c|c|c|c|c|}
\hline & & Phase I & Phase II & Phase III & Phase IV \\
\hline$\Delta \dot{V O O}_{2} \mathrm{I}(\%)$ & $\begin{array}{l}\mathrm{C} \\
\mathrm{ECR}\end{array}$ & - & $\begin{array}{l}+155 \pm 93 \\
+102 \pm 99\end{array}$ & $\begin{array}{l}+25 \pm 27 \\
+19 \pm 34\end{array}$ & $+26 \pm 27$ \\
\hline$\Delta \dot{\mathrm{VCO}}{ }^{2} \mathrm{I}(\%)$ & $\begin{array}{l}\mathrm{C} \\
\mathrm{ECR}\end{array}$ & - & $\begin{array}{l}+217 \pm 76 \\
+176 \pm 130\end{array}$ & $\begin{array}{l}+46 \pm 20 \\
+30 \pm 17\end{array}$ & $+51 \pm 24$ \\
\hline$\triangle \dot{V}$ EBTPS $(\%)$ & $\begin{array}{l}\text { C } \\
\text { ECR }\end{array}$ & $\begin{array}{l}+1 \pm 12 \\
+8 \pm 11\end{array}$ & $\begin{array}{l}+148 \pm 38 \\
+154 \pm 97\end{array}$ & $\begin{array}{l}+23 \pm 21 \\
+21 \pm 26\end{array}$ & $-2 \pm 17$ \\
\hline Time in ICU (h) & $\begin{array}{l}\text { C } \\
\text { ECR }\end{array}$ & $\begin{array}{l}0.5 \\
0.5\end{array}$ & $\begin{array}{l}2.5 \\
2.5\end{array}$ & $\begin{array}{l}4.5 \\
* \quad 3.5\end{array}$ & 6.5 \\
\hline
\end{tabular}

Mean \pm SD are given. The median times (h) of the phases are also given. $C=$ control, $E C R=$ extended CPB-rcwarming group. Group to group differences are indicated by $*=p<0.05, \dagger=p<0.01, \ddagger=p<0.001$.

Values of phase IV were not included in the statistical comparisons since data were not available for all patients in the ECR group ( $n=4$ ).

patients exhibited very little or no shivering. In previous reports it has been difficult to correlate the presence of postoperative shivering with the degree of hypothermia. ${ }^{7,17}$ Our present experience and other reports ${ }^{18,19}$ suggest that such a relation does exist.

In phase II, oxygen uptake, carbon dioxide production and ventilation volume were similar in both groups even though shivering was reduced in the ECR group. This may be explained as an effect of non-shivering thermogenesis $\mathrm{s}^{20}$ and of the higher body temperature in that group. Oxygen uptake and carbon dioxide production were significantly reduced in the non-shivering subgroup of the ECR group when compared with the subgroup of shivering patients. Such a difference between shivering and non-shivering patients, even though hypothermic, has been reported previously. ${ }^{6.7}$

The shivering subgroup also required significantly increased ventilatory volumes, had a significantly increased peripheral oxygen extraction, and showed a significant decrease in arterial base excess. These changes were at least as large as in the control group, indicating metabolic and circulatory consequences of hypothermia and shivering, that were present in spite of secured adequate ventilation and not reliably influenced by extended $C P B$ rewarming.

In both groups adequate ventilation was accomplished even though the demands could alter within 15-20 minutes by at least 100 per cent between basal and peak values at the onset or cessation of shivering. This required the continuous end-tidal $\mathrm{CO}_{2}$ monitoring and continuous highly qualified surveillance of the patient. Continued postoperative use of muscle relaxants and/or postopera-
TABLE IV Comparisons of some variables at phase II in shivering ( $n=9$ ) and non-shivering $(n=7)$ patients in the extended CPB-rewarming group

\begin{tabular}{lcc}
\hline & Shivering & Non-shivering \\
\hline$\dot{\mathrm{VO}}_{2} \mathrm{I}\left(\mathrm{mmol} \cdot \mathrm{s}^{-1} \cdot \mathrm{m}^{-2}\right)$ & $0.255 \pm 0.055 \neq$ & $0.141 \pm 0.0249$ \\
$\dot{\mathrm{V}} \mathrm{CO}_{2} \mathrm{I}\left(\mathrm{mmol} \cdot \mathrm{s}^{-1} \cdot \mathrm{m}^{-2}\right)$ & $0.207 \pm 0.030 \neq$ & $0.101 \pm 0.026$ \\
$\dot{\mathrm{V}}_{\mathrm{E} B T S}\left(\mathrm{~L} \cdot \mathrm{min}^{-1}\right)$ & $22.1 \pm 2.9 \ddagger$ & $10.6 \pm 3.1$ \\
$\Delta \mathrm{T}_{\mathrm{os}}\left({ }^{\circ} \mathrm{C}\right)$ & $1.4 \pm 0.8^{*}$ & $0.7 \pm 0.2$ \\
$\mathrm{O}_{2}$ utilization coefficient & $0.62 \pm 0.13^{*}$ & $0.46 \pm 0.10$ \\
$\mathrm{aB}-\mathrm{BE}\left(\mathrm{mmol}^{-1} \mathrm{~L}^{-1}\right)$ & $-2.7 \pm 3.9^{*}$ & $1.5 \pm 1.8$ \\
$\mathrm{CI}\left(\mathrm{L} \cdot \mathrm{min}^{-1} \cdot \mathrm{m}^{-2}\right)$ & $3.1 \pm 0.5 \mathrm{n} . \mathrm{s}$. & $2.6 \pm 0.5$ \\
\hline
\end{tabular}

Mean $\neq \mathrm{SD} .{ }^{*}=\mathrm{p}<0.05, \dagger=\mathrm{p}<0.01 \ddagger=\mathrm{p}<0.001 . \Delta \mathrm{T}_{\text {oes }}$ denotes the change in $\mathrm{T}_{\text {oes }}$ relative to the preceding measurement.

tive heavy morphine medication are measures that have been shown to reduce shivering and the increased metabolic requirements. ${ }^{21,22}$ This approach requires prolonged postoperative ventilator treatment and does not improve the prolonged postoperative peripheral vasoconstriction and reduced peripheral perfusion, as reflected by the finger skin temperature. The meticulous adjustments of ventilation as well as the pharmacological treatment, however, all represent partially effective but symptomatic measures not directed at the underlying hypothermia.

Further improvement in CPB rewarming seems to be required in order to obtain reliable beneficial effects on the postoperative consequences of residual hypothermia. The rewarming may be enhanced by the use of pulsatile flow. ${ }^{23}$ Further attempts to improve the distribution of the heat supplied during CPB include increased pump flow and blood pressure, ${ }^{24}$ and use of vasodilating agents. ${ }^{25}$ We have found that even in the presence of residual 
hypothermia, the postoperative heat balance can be improved with postoperative external heat supply, which also significantly reduces shivering, oxygen uptake, ventilation requirements and ameliorates vasoconstriction. ${ }^{8}$ This seemed more efficient and reliable than the results of the present study of extended rewarming during cardiopulmonary bypass. Nevertheless it seemed better to let rectal temperature rather than nasopharyngeal temperature guide the rewarming on CPB.

\section{Conclusions}

Extended $\mathrm{CPB}$ rewarming may reduce the heat deficit usually seen after hypothermic cardiopulmonary bypass. It reduced postoperative shivering. However, the beneficial effects on metabolic and ventilatory requirements seen in some patients were not uniform and were quite unpredictable. In fact, overall comparisons between the entire extended CPB-rewarming group and the control group did not reveal any improvements in metabolic or ventilatory requirements due to the extended rewarming.

It therefore seems inefficient when used alone to improve the postoperative course after cardiac surgery, but it may be of value as a complementary measure if combined, for instance, with postoperative radiant heat supply.

\section{Acknowledgement}

The authors want to thank Marcelle Bertram-Guy, R.N., for her excellent skilled technical assistance during the investigation.

\section{References}

1 Davis FM, Parimelazhagan KN. Harris EA. Thermal balance during cardiopulmonary bypass with moderate hypothermia in man. Br J Anaesth 1977; 49: 1127-32.

2 Shanks $C A$, Wade $L D$, Meyer $R$, Wilkinson $C J$. Changes of body temperature and heat in cardiac surgical patients. Anaesth Intensive Care 1984; 13: 12-7.

3 Sladen RN. Temperature and ventilation after hypothermic cardiopulmonary bypass. Anesth Analg 1985; 64: 816-20.

4 Muravchick S, Conrad DP, Vargas A. Peripheral temperature monitoring during cardiopulmonary bypass operation. Ann Thorac Surg 1980; 29: 36-41.

5 Ramsay JG, Ralley FE, Whalley DG, DelliColli $P$, Wynands $J E$. Site of temperature monitoring and prediction of afterdrop after open heart surgery. Can Anaesth Soc J 1985; 32: 607-12.

6 Ralley FE. Carli F, Ramsay JG, Wynands JE. Oxygen consumption and carbon dioxide production in patients following open heart surgery (Abstract). Can Anaesth Soc J 1986; 33: $\$ 70-\$ 71$.
7 Bay J, Nunn JF, Prys-Roberts C. Factors influencing arterial $\mathrm{PO}_{2}$ during recovery from anaesthesia. $\mathrm{Br} \mathrm{J}$ Anaesth 1968; 40: 398-406.

8 Joachimsson $P-O$, Nysiröm $S-O, T y d e ́ n ~ H$. Postoperative ventilatory and circulatory effects of heating after aortocoronary bypass surgery. Postoperative external heat supply. Acta Anaesthesiol Scand 1987; 31: 532-42.

9 Engström C-G, Herzog $P$. Ventilation nomogram for practical use with the Engström respirator. Acta Chir Scand (Suppl) 1959; 245; 37-42.

10 Joachimsson $P$ - $O$, Nyström S-O, Tyden $H$. Heating efficacy of external heat supply during and after open heart surgery with hypothermia. Acta Anacsthesiol Scand 1987; 31: 73-80.

11 Rahn $H$, Reeves $R B$. Hydrogen ion regulation during hypothermia: from the Amazon to the operating room. In: Prakash O, (Ed). Applied physiology in clinical respiratory care. The Hague: Martinus Nijhoff Publishers 1982: 1-15.

12 Ramanathan NL. A new weighting system for mean surface temperature of the human body. J Appl Physiol 1964; 19: 531-3.

13 Burton $A C$. Human calorimetry. II. The average temperature of the tissues of the body. J Nutr 1935; $9: 261-80$.

14 Winer BJ. Statistical Principles in Experimental Design. 2nd ed. New York: McGraw Hill Company (Psychology Series), 1971: 525-529, 599-603.

15 Holdcrofi $A$. Body temperature control in anaesthesia, surgery and intensive care. London: Baillière Tindall 1980: $106-46$.

16 Cork RC, Vaughan RW, Humphrey LS. Precision and accuracy of intraoperative temperature monitoring. Anesth Analg 1983; 62: 211-4

17 Cohen $M$. An investigation into shivering following anaesthesia. Preliminary report. Proc R Soc Med 1967; 60: $752-3$.

18 Pflug AE, Aasheim GM, Foster C, Martin RW. Prevention of post-anaesthetic shivering. Can Anaesth Soc J 1978; 25: 43-9.

19 Vaughan MS, Vaughan RW, Cork RC. Postoperative hypothermia in adults: relationship of age, anesthesia, and shivering to rewarming. Anesth Analg 1981;60: $746-51$.

20 Jessen $K$. An assessment of human regulatory nonshivering thermogenesis. Acta Anaesthesiol Scand 1980; 24: 138-43.

21 Rodriguez JL, Weissman C, Damask MC et al. Physiological requirements during rewarming: suppression of the shivering response. Crit Care Med 1983; 11: 490-7.

22 Rodriguez JL, Weissman C, Damask MC et al. Morphine and postoperative rewarming in critically ill patients. Circulation 1983; 68: 1238-46. 
23 Williams $G D$, Seifen $A B$, Lawson $N W$, et al. Pulsatile perfusion versus conventional high-flow nonpulsatile perfusion for rapid core cooling and rewarming of infants for circulatory arrest in cardiac operation. I Thorac Cardiovasc Surg 1979; 78: 667-77.

24 Stanley HT, Jackson J. The influence of blood flow and arterial blood pressure during cardiopulmonary bypass on deltoid muscle gas tensions and body temperature after bypass. Can Anaesth Soc J 1979; 26: 277-81.

25 Noback $C R$, Tinker $J H$. Hypothermia after cardiopulmonary bypass in man: amelioration by nitroprussideinduced vasodilation during rewarming. Anesthesiology 1980; 53: $277-80$.

Résumé

Eude des effets postopératoire du réchauffement prolongé $(E C R)$ après une operation faite avec circulation extracorporelle (CEC) et hypothermie. On a réchauffé tous les malades $(n=28)$ jusqu'à ce que la tempéralure du nasopharynx ait dépassé $38^{\circ} \mathrm{C}$ avant la fin de la période en CEC. Douze malades (groupe de contrôle) ont eu une température rectale $\left(T_{r e}\right)$ de $33.8 \pm 1.7^{\circ} \mathrm{C}$ (moyenne $\pm s d$ ) à la fin de la période en CEC. Durant le CEC on a réchauffé seize malades (groupe dénommé ECR) jusqu' à ce

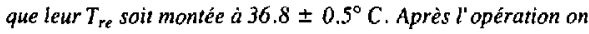
a mesure les températures en diverses places du corps, la quantité du chaluer, l'hyperactivité musculaire, le degré d'oxygène, la production de $\mathrm{CO}_{2}$ et les différentes phases de l' haemodynamique. Le procédé par ECR a réduit le besoin de chaleur nécessaire pour le réchauffement central à $665 \pm 260 \mathrm{~kJ}$. A comparer aux $1037 \pm 374 \mathrm{~kJ}$ dans le groupe de contrôle $(p<0.01)$. La manifestation de l'hyperactivité musculaire a été réduite $(p<$ $0.05)$ aussi bien que son intensité et sa durée. Chez sept malades du groupe ECR l'absence d' hyperactivité musculaire a coincidé avec une réduction significative au point de vue du métabolisme et de la ventilation mais ce genre d'amélioration n'est pas valable pour le groupe pris dans son ensemble. Après l'operation, le débit ventilatoire dans la période de réchauffement a augmenté dans les deux groupes de 250 pour cent au-dessus du niveau de base. Prolonger le réchauffement en CEC jusqu' atteindre au moins $36^{\circ} \mathrm{C}$ rectal n'a pas été une méthode efficace si on I'emploie seule pour réduire après l'opération les effets indésirables de l' hypothermie pratiquée en CEC. 